\title{
Settling/Sedimentation Followed by Sorption with Pinus sylvestris Sawdust as "Green" Sorbent: On-Site Treatment of a Real Industrial Wastewater
}

\author{
Fabio Kaczala1, Marcia Marques ${ }^{1,2}$, William Hogland ${ }^{1}$ \\ ${ }^{1}$ Department of Biology and Environmental Science, Linnaeus University, Kalmar, Sweden \\ ${ }^{2}$ Department of Sanitary and Environmental Engineering, Rio de Janeiro State University, Rio de Janeiro, Brazil \\ Email: fabio.kaczala@Inu.se
}

Received 11 February 2014; revised 12 March 2014; accepted 11 April 2014

Copyright (C) 2014 by authors and Scientific Research Publishing Inc.

This work is licensed under the Creative Commons Attribution International License (CC BY).

http://creativecommons.org/licenses/by/4.0/

(c) (i) Open Access

\section{Abstract}

Whereas the pulp and paper industrial sector-considered the second highest consumer of freshwater in Europe-has already been provided with sufficient wastewater characterization and treatment technologies, other wood-based industries (e.g. furniture, floor production), which do not use water for manufacturing processes, generate different wastewater streams after: 1) cleaning/washing of machinery that applies adhesives and coatings onto wood surfaces; 2 ) cleaning/washing of machinery that applies specific products for the curing phase of adhesives; 3 ) cleaning/washing of sharp planar blades used for the sawn process and to prepare wood surfaces for the adhesive application; 4) cleaning/washing of the floor; 5) cleaning/washing of trucks and vehicles. The dilution of low-volumes of highly polluted wastewater is not acceptable any longer since conventional treatment plants are not designed for these types of industrial wastewater. There is a need for proper characterization, treatability studies, designing and testing alternative small size and cost-effective treatment systems for on-site implementation. Treatment systems based on sorption mechanisms are flexible, easy to operate and generate less sludge and several low-cost sorbents generated by forestry activities have advantageous physico-chemical characteristics. The current paper presents the preliminary results from a pilot treatment system consisting of an equalization tank, settling/sedimentation and two sorption reactors in parallel using Pinus sylvestris sawdust as sorbent implemented as part of an integrated water management plan in a wood-floor industry. The simple to operate and cost-effective pilot treatment system performs satisfactorily during an initial period of operation. The study shows an average $39 \%-54 \%$ reduction of TPH; $17 \%-38 \%$ reduction of oil; $2 \%-15 \%$ of reduction of COD and; $11 \%-74 \%$ reduction of most toxic metals but for $\mathrm{Co}, \mathrm{Ni}$ and $\mathrm{Zn}$ in the system B. Based on these results, Pinus sylvestris sawdust is a potential low-cost and abundant material to be considered for industrial wastewater treatment plants.

How to cite this paper: Kaczala, F., et al. (2014) Settling/Sedimentation Followed by Sorption with Pinus sy/vestris Sawdust as “Green" Sorbent: On-Site Treatment of a Real Industrial Wastewater. Journal of Environmental Protection, 5, 368-375. 


\section{Keywords}

\section{Industrial Wastewater, Treatment, Sorption, Sawdust, Pinus sylvestris, Sedimentation}

\section{Introduction}

Wood is a well-known raw material for the manufacturing of several products such as houses, furniture and paper and as fuel for district heating and electricity in cold climate countries. According to [1], the per capita consumption of paper and associated products has been dramatically increasing, being this industrial sector, the second largest consumer of freshwater in Europe, with a generation of considerable volumes of wastewater ranging between $10-50 \mathrm{~m}^{3}$ of wastewater per ton of paper produced. Characterization, treatment options for such industrial wastewaters and efficiency of established plants have been extensively reported in the literature [1] since the end of 1970's, when the first anaerobic processes in paper mill industries are introduced. [2] highlighted that by the end of 1980's at least 33 full-scale anaerobic treatment plants were in operation treating these types of effluents. Moreover, intensive pilot and laboratory studies had demonstrated the suitability of anaerobic processes for treating wastewater from paper mill industries. By that time, environmental impacts in Finland were described, leading to the implementation of aerobic activated sludge treatment plants [3]. Data from aerobic treatment plants for paper-mill wastewater were also presented by [4], mentioning that in Germany, since 1989 up-flow aerobic submersed biological film reactors were in operation, and in 1998, among 20 similar plants operating throughout the world, 13 were located in Germany. [5] carried out an extensive chemical characterization in parallel with anaerobic bio-treatability tests. In 1999, whereas [6] studied the fate of resin acids released from wood pulping during biological treatment, [7] developed an advanced treatment system to maximize the treatment efficiency.

Toxic metals and petroleum hydrocarbons are found in wastewaters discharged from several industrial activities such as mining, smelters, electroplating, dyes, textiles, tanneries, oil refineries, food industries, wood-based factories and others [8]. Nowadays, the most widely applied methods for metal removal from wastewaters are: chemical and electrochemical precipitation [9] [10]; cationic and anionic ion-exchange resins [11]; membrane filtration and sorption [11]. Sorption methods might be considered flexible, cheap and easy to operate and maintain. As a consequence, the use of different types of "non-conventional" sorbents with advantageous physical and chemical surface characteristics has been extensively investigated [12]. During the last years, the efficiency and behavior of several sorbents able to sequester toxic metals from contaminated waters have been reported, such as biomass waste from biological wastewater treatment system [13] [14]; cotton boll [15]; pollens [16]; teak leaves powder [17]; black gram husk [18]; grape stalk [19]; peat [20]; fly ash [21]; wood barks [22] [23] and; sawdust [8]. Regarding petroleum hydrocarbons, sorption studies have focused mostly on soil particles as sorbents [24]. Other sorbents tested for removal of petroleum hydrocarbons are: organozeolites and clays [25]; cotton fibres [26]; walnut shells [27]; chrome shavings [28] and granulated activated carbon [29].

Among a number of "non-conventional" sorbents being investigated, agricultural and forestry waste materials have attracted special attention, once these materials can be considered as low-cost and abundant [30]. In this context, wood sawdust can be considered one of the most promising and abundant sorbents available in woodbased industries making its use for wastewater treatment reasonable.

This study is a part of a large research project in which the main goal is to develop an innovative approach for onsite integrated management of industrial wastewater and storm water generated in wood-floor and wood-furniture industries, prioritizing non-conventional low-cost systems. In the present paper, a low-cost pilot treatment plant, which combined gravitational settling/sedimentation process with sorption by using Pinus sylvestris sawdust as sorbent was developed, based on previous knowledge obtained in laboratory studies [8].

The ultimate goal was to develop simple and cost-effective coupled treatment methods to remove toxic metals and petroleum hydrocarbons found in wastewater streams generated by a wood floor industry during equipment, machinery and floor washing procedures. The use of environmental friendly and "green" materials such as the Pinus sylvestris sawdust sorbent that can be considered waste generated by the wood industrial sector has been highlighted. 


\section{Material and Methods}

\subsection{Wastewater}

A mixture of three wastewater streams was studied: two streams generated during floor washing procedures in two different areas within a wood-floor industry located in the south-eastern part of Sweden (Figure 1), and a third one generated during washing of metallic blades used to cut and saw wood boards. As previously mentioned, the pilot treatment plant herein evaluated was based on the knowledge obtained in laboratory studies which Pinus sylvestris sawdust was tested as sorbent to remove toxic metals and hydrocarbons from similar industrial wastewaters [8].

\subsection{The Pilot Plant}

The pilot treatment plant was operated in batch mode during 27 weeks and had the following sequential units as observed in Figure 2: (1) an Equalization tank; (2) a settling/sedimentation tank and two similar sorption units installed in parallel; (3a) and (3b).

Each unit of the treatment plant is briefly described below.

Equalization tank-The total volume $\left(\mathrm{V}_{\mathrm{t}}\right)$ of the equalization tank was approximately $1000 \mathrm{~L}$. The equalization tank had a propeller that was constantly running in a low rotation speed to perform the mixing and equalization of raw wastewater in order to avoid settling of particulate matter.

Sorption units-The total volume $\left(\mathrm{V}_{\mathrm{t}}\right)$ of each sorption unit (iii) and (iv) was approximately $140 \mathrm{~L}$ (Internal Height $=0.80 \mathrm{~m}$, External height $=0.88 \mathrm{~m}$; Diameter $=0.57 \mathrm{~m})$, and the effective volume $\left(\mathrm{V}_{\mathrm{e}}\right)$ applied in every batch was approximately $90 \mathrm{~L}$ (water depth equivalent to $0.56 \mathrm{~m}$ ). Four sampling points (Figure 3 ) were established; however in this present study only sampling points S1, S3 and S4 were considered. The Hydraulic Retention times (HRTs) in the entire system (settling + sorption reactor) were either 4 or 7 days

\subsection{Analytical Chemistry}

Samples were collected in $1 \mathrm{~L}$ glass bottles, transported to the laboratory and stored in $4^{\circ} \mathrm{C}$ in the dark until further analysis. For total metal contents samples were transferred as soon as arrived in the laboratory to $50 \mathrm{~mL}$ polyethylene tubes previously rinsed with diluted nitric acid (10\% v/v). Analysis was done for: 1$)$ metals: Arsenic-As; Barium-Ba; Lead-Pb; Cadmium-Cd; Chromium-Cr; Cobalt-Co; Iron-Fe; Copper-Cu; Mercury-Hg; Nickel-Ni; Vanadium-V; Zinc-Zn and; Manganese-Mn); 2) two fractions of hydrocarbons (total extractable aliphatic compounds; total extractable aromatic compounds) and Oil 3) total COD. Metals were analysed by an inductively coupled plasma mass spectrometry (ICP-MS) [31] and total COD with Dr Lange analytical kits LCK 114 (Dr Bruno Lange, Dusseldorf -Germany) and measured with HACH XION 500 spectrophotometer. Hydrocarbons were analysed using a gas chromatography with a flame ionization detector (GC-FID) by applying a modified version of the method NEN 6978 [32]. Wastewaters were collected and analysed without any pre-treatment unless previously stated.

\section{Results}

Although several metals were analysed due to their toxic properties, those metals that were detected in low concentrations were considered out of concern in this work. The treatment performance herein presented has considered the overall efficiency achieved by the entire treatment process (settling/sedimentation + sorption unit) as it can be observed in Table 1 and Table 2. Two different sorption units' 3a and 3b (Figure 3) were operated in parallel simultaneously being classified as combined treatment A and B respectively. Therefore System A consisted of Settling/sedimentation + Sorption unit 3a (Table 1) and System B consisted of Settling/sedimentation + sorption unit 3b (Table 2).

\section{Discussions}

It is widely known that hydraulic retention time plays important roles on the transformation and removal of different contaminants in wastewater treatment systems. However, by taking into account the complexity of the studied wastewaters containing a large number of inorganic and organic compounds, it was not possible to sug- 


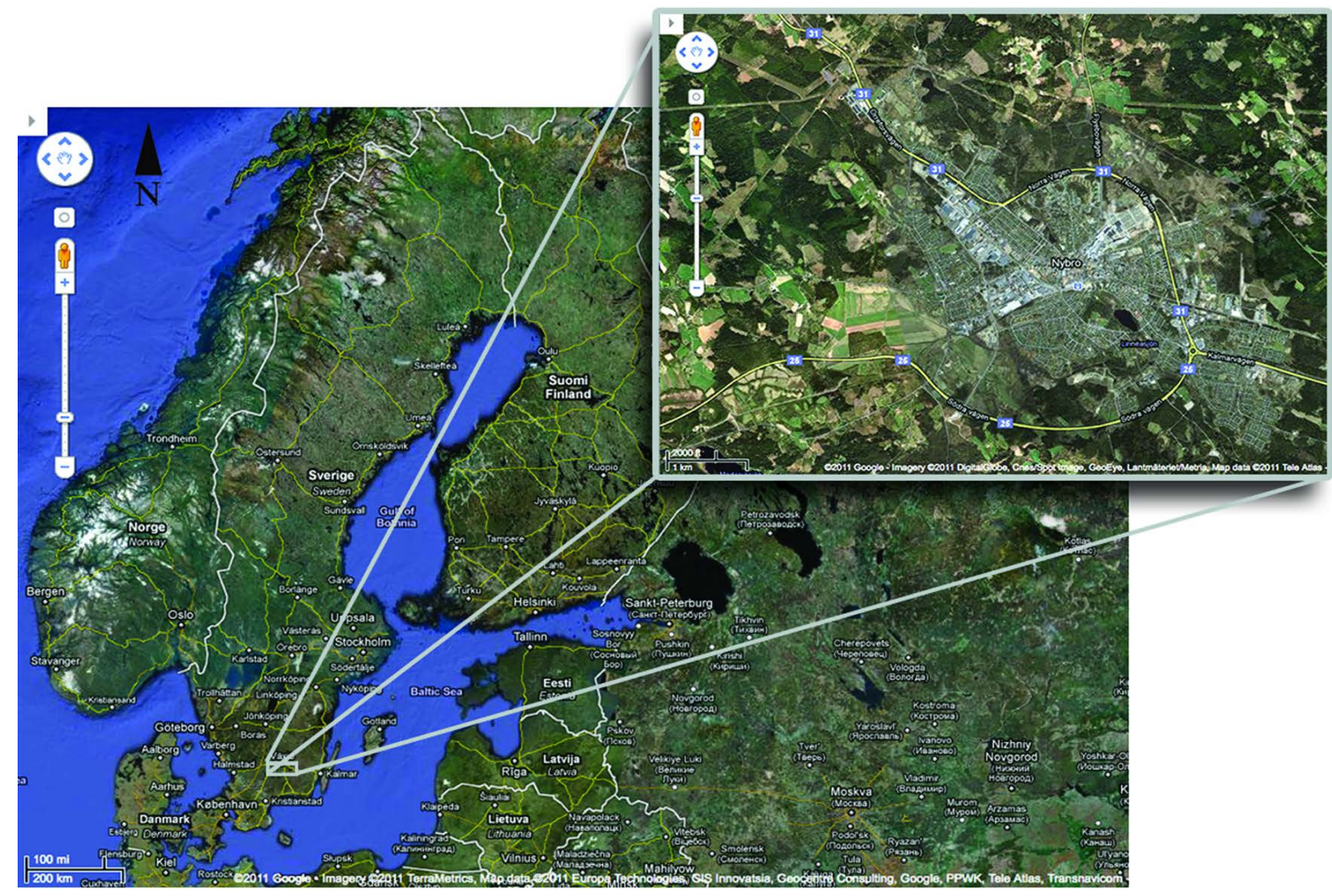

Figure 1. Geographical locations of the study site and an aerial view in detailed scale. (Sources: (C2011 Google-image (C2011 TerraMetrics, Kartdata C2011 Europa Technologies, GIS Innovatsia, Geocentre Consulting, Google, PPWK, TeleAtlas, (C2011 DigitalGlobe, Cnes/Spot Image, GeoEye, Lantmäteriet Metria).

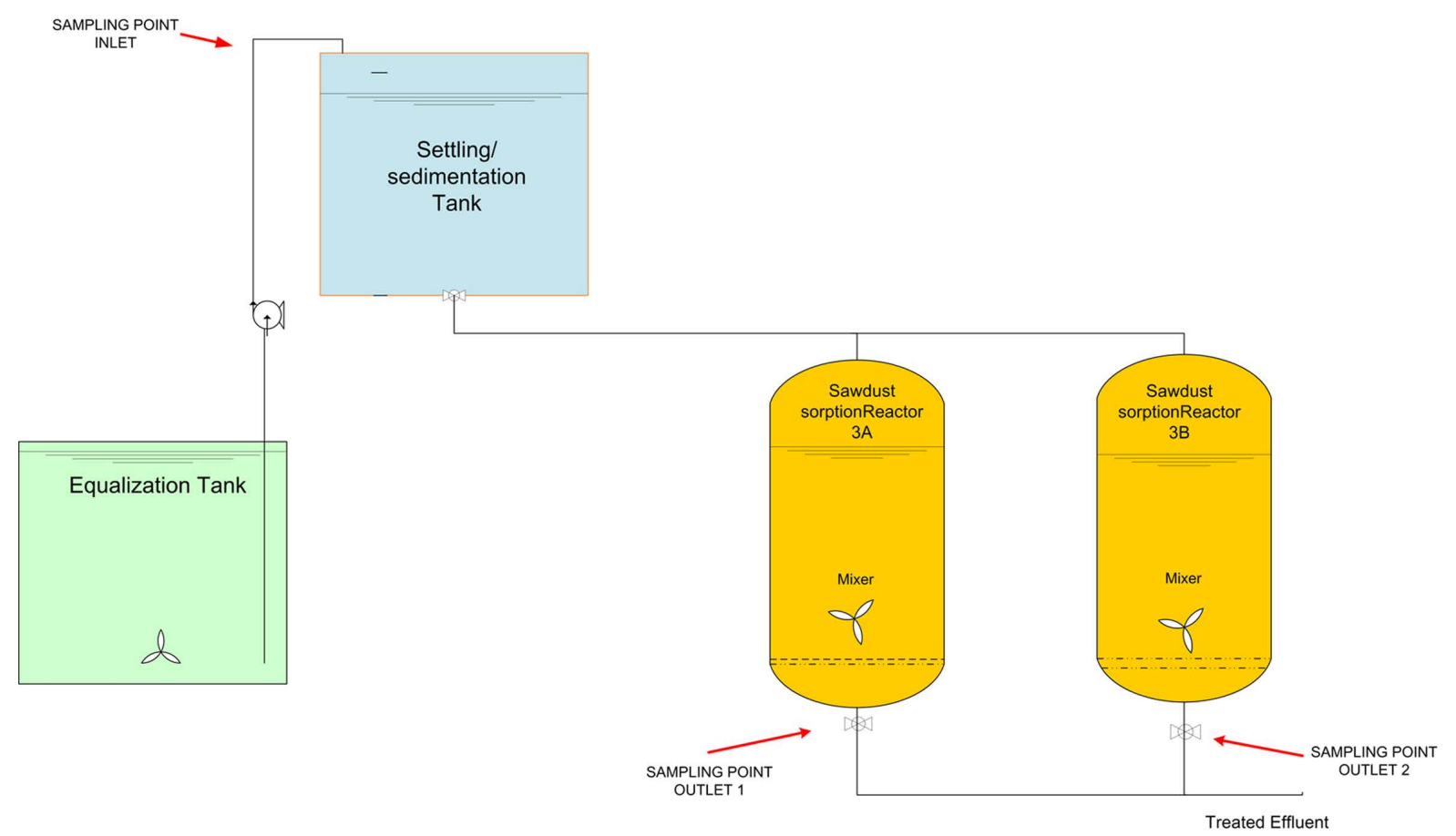

Figure 2. Pilot treatment system consisting of: (1) Equalization tank; (2) Settling/sedimentation tank; (3a) and (3b) Sorption units. 


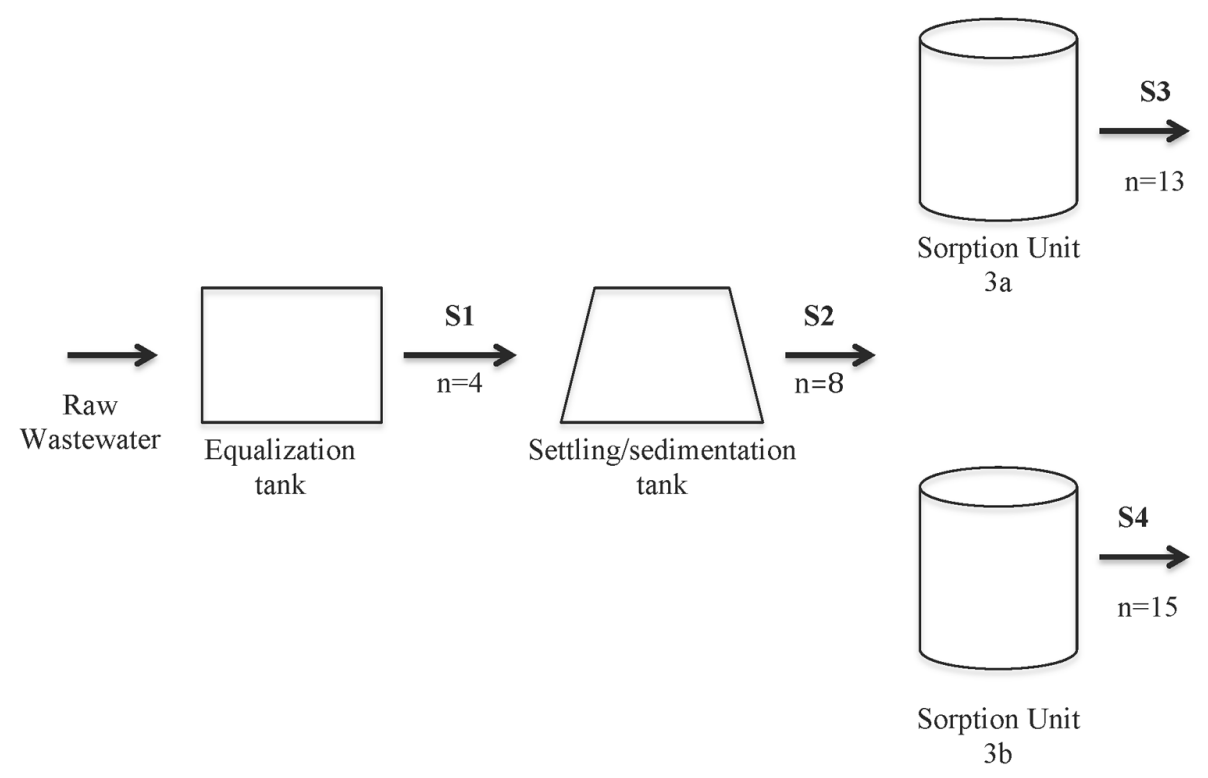

Figure 3. Schematic drawing of the system and its respective sampling points.n = number of samples. (S1) Outlet equalization tank = Inlet settling/sedimentation; (4 samples); (S2) Outlet settling/sedimentation = Inlet of sorption units (iii) and (iv) (8 samples); (S3) Outlet of sorption reactor 3a and (13 samples); (S4) Outlet of sorption reactor 3b (15 samples).

Table 1. Inlet and outlet characteristics of the pilot treatment system A.

\begin{tabular}{|c|c|c|c|c|c|}
\hline & \multicolumn{2}{|c|}{ Inlet (S1) } & \multicolumn{2}{|c|}{ Outlet (S3) } & \multirow{2}{*}{$\begin{array}{c}\text { Average } \\
\text { Efficiency (\%) }\end{array}$} \\
\hline & Mean conc & $\mathrm{SE}^{1}$ & Mean conc & $\mathrm{SE}^{1}$ & \\
\hline $\mathrm{TPH}^{*}$ & 3700 & 821 & 1627 & 76 & $56 \pm 5$ \\
\hline $\mathrm{Oil}^{*}$ & 890 & 254 & 471 & 87 & $47 \pm 22$ \\
\hline $\mathrm{COD}^{*}$ & 116857 & 18789 & 101571 & 14513 & $2 \pm 35$ \\
\hline $\mathrm{Ba}^{* *}$ & 220 & 31 & 94 & 50 & $58 \pm 28$ \\
\hline $\mathrm{Pb}^{* *}$ & 84 & 2 & 25 & 7 & $70 \pm 22$ \\
\hline $\mathrm{Cr}^{* *}$ & 56 & 4 & 40 & 1.5 & $26 \pm 17$ \\
\hline $\mathrm{Co}^{* * *}$ & 22 & 4 & 23 & 2 & $-12 \pm 25$ \\
\hline $\mathrm{Cu}^{* *}$ & 415 & 59 & 307 & 61 & $30 \pm 14$ \\
\hline $\mathrm{Ni}^{* *}$ & 47 & 5 & 70 & 5 & $-58 \pm 48$ \\
\hline $\mathrm{Zn}^{* *}$ & 7715 & 324 & 7471 & 1419 & $4 \pm 8$ \\
\hline
\end{tabular}

${ }^{1}$ Standard error of the Mean; ${ }^{*} \mathrm{ppm} ;{ }^{* *} \mathrm{ppb}$.

gest an optimum retention time for the treatment process, since each of these compounds interacted in a different way with the wood-based sorbents within the system. The results suggest that different compounds have different optimum range of retention time in which, their removal would reach the highest efficiency. Another important aspect is that the sorption reactions that took place within the sorption units were likely to be reversible, meaning that not only sorption but also desorption usually occurred. These reversible reactions might be a consequence of the competition among different chemical constituents for sorptive sites in Pinus sylvestris sawdust particles. Therefore, the optimum HRT to be selected must be the one that in an overall evaluation is the most appropriate for most contaminants present in the wastewater. Therefore, neither a short nor a long time is needed, but a specific retention period in which most of the substances would be uptaken in a satisfactory amount onto the Pinus sylvestris sawdust.

An important operational change that reflected in the final efficiency of the treatment plant consisted in turning off the propellers within the sorption units for approximately one hour, prior the final effluent discharges, 
Table 2. Inlet and outlet characteristics of the pilot treatment system B.

\begin{tabular}{|c|c|c|c|c|c|}
\hline & \multicolumn{2}{|c|}{ Inlet (S1) } & \multicolumn{2}{|c|}{ Outlet (S3) } & \multirow{2}{*}{$\begin{array}{c}\text { Average } \\
\text { Efficiency (\%) }\end{array}$} \\
\hline & Mean conc & SE1 & Mean conc & SE1 & \\
\hline $\mathrm{TPH}^{*}$ & 3700 & 821 & 2060 & 276.5 & $45 \pm 18$ \\
\hline $\mathrm{Oil}^{*}$ & 890 & 254 & 737 & 111 & $28 \pm 33$ \\
\hline $\mathrm{COD}^{*}$ & 108000 & 15500 & 99967 & 5341 & $2 \pm 23$ \\
\hline $\mathrm{Ba}^{* *}$ & 197 & 24 & 146 & 34 & $29 \pm 30$ \\
\hline $\mathrm{Pb}^{* *}$ & 82 & 2 & 29 & 7 & $65.5 \pm 22$ \\
\hline $\mathrm{Cr}^{* *}$ & 54 & 4 & 43 & 2 & $19 \pm 13$ \\
\hline $\mathrm{Co}^{* * *}$ & 20 & 2.5 & 21 & 2 & $-10 \pm 12$ \\
\hline $\mathrm{Cu}^{* *}$ & 377 & 44.5 & 316 & 94.5 & $28 \pm 43$ \\
\hline $\mathrm{Ni}^{* *}$ & 45 & 4 & 83 & 14 & $-84 \pm 57$ \\
\hline $\mathrm{Zn}^{* *}$ & 7867 & 267 & 8500 & 430 & $-8 \pm 13$ \\
\hline
\end{tabular}

${ }^{1}$ Standard error of the Mean; ${ }^{*} \mathrm{ppm} ;{ }^{* *} \mathrm{ppb}$.

instead of the standard procedure of discharging immediately after turning off the mixer. The results suggested that when the mixer is off for a certain period, a large portion of the sawdust is settled down, creating at the bottom of the reactor a sort of sawdust filter. Under these circumstances, the wastewater percolates through it downwards to the outlet. Interestingly, the reduction of compounds achieved by the system under this specific operational procedure was remarkably superior. This effect illustrates that a simple modification of the operational procedure might bring considerable improvements to the final efficiency of the treatment plant. The hypothesis of physical filtration by the sawdust is being currently investigated in more details in laboratory scale, and if confirmed, it will lead to an innovative and simple treatment system with two different processes-sawdust sorption followed by sawdust physical filtration — taking place inside the sorption unit.

The results presented in the Table 1 and Table 2 indicate that such low cost simple treatment system tested at the wood floor industry performed satisfactorily. The compounds in higher concentration range (mg L $\left.\mathrm{m}^{-1}\right) \mathrm{such}$ as TPH (Total Petroleum Hydrocarbons) and oils had their concentrations efficiently decreased by an average of 54 and 38\% (System A); and 39 and 17\% (System B) respectively. Such reduction efficiencies can be considered acceptable in a cost-efficiency approach (mainly for the system A). Regarding the COD (Chemical Oxygen Demand), that is the parameter with the largest range of inflow concentrations (Table 1 and Table 2), the system still has weaknesses and further improvement in the equalization system is required. High COD values and difficulties for reduction might be related with the amount of detergents that probably require advanced chemical oxidation to be broken down. An additional aspect that might be posing negative influence over the COD reduction is the release of specific compounds from the sawdust, such as tannins, lignin, phenols, cellulose and some resin acids.

When considering the overall performance of the system B, Nickel, Cobalt and Zinc had their mean concentrations increased after treatment. However, considering the low range of concentrations $\left(\mu \mathrm{g} \mathrm{L}^{-1}\right)$ of such metals in the effluent, negative reductions are out of concern. On the other hand, an effort is clearly required to achieve an increased Zinc removal, since this metal occurs in considerable high concentrations in the studied wastewater. Similarly, the system A had negative reduction \% of $\mathrm{Ni}$ and Co but no concern due to same reasons are raised. Differently than System B, System A had a positive average removal of Zn with average reduction as low as $4 \%$. It was observed that $\mathrm{Pb}$ removal was quite comparable in both reactors with average removal rates of $70 \% \pm 22 \%$ and $65.5 \% \pm 22 \%$ in system A and B respectively. Furthermore both reactors had similar performance concerning the removal of TPHs and $\mathrm{Cu}$ as observed in Table 1 and Table 2 . Whereas TPHs removal rates of 56\% $\pm 5 \%$ and $45 \% \pm 18 \%$ were observed in the System A and System B respectively, Cu was reduced by $30 \% \pm 14 \%$ and $28 \% \pm 43 \%$.

\section{Conclusion}

In a scenario where society searches for sustainability, the generation of low volumes ( $\approx \mathbf{1 0 0 0}$ - 2000 liters/week) of highly polluted industrial wastewaters after cleaning and washing procedures followed by dilution with drinking water and further discharge into municipal wastewater treatment plants should be no longer acceptable. 
The design and establishment of new strategies considering low-cost onsite treatment systems might be a part of an integrated sustainable management of water in industrial sites. The simple to operate and cost-effective pilot treatment system based on equalization, settling/sedimentation, sorption and filtration processes has performed satisfactorily during an initial period of operation. The study shows an average reduction of $39 \%-54 \%$ for TPH; $17 \%-38 \%$ reduction for oil; $2 \%-15 \%$ of reduction of COD and; $11 \%-74 \%$ reduction of most toxic metals but for $\mathrm{Co}, \mathrm{Ni}$ and $\mathrm{Zn}$ that had increased concentrations in the system B. Based on the preliminary results obtained during approximately 6 months of continuous monitoring, it is suggested that such a system, regardless the need for additional improvements and a better understanding of inherent processes, has a potential to be implemented for the treatment of wastewater streams generated by wood floor industries during cleaning and washing of floors and machinery. It is recommended that these industries should develop: 1) full-control of environmental effects created by their activities and; 2) technologies to prevent and treat wastewaters, minimizing as much as possible the pollution load on municipal wastewater treatment plants and on receiving water bodies.

\section{Acknowledgements}

The Knowledge Foundation in Sweden and CAPES Foundation in Brazil is acknowledged for the financial support. Special acknowledgement goes to the Environmental Manager ÅkeErlandsson at AB GustafKähr, Sweden for the support and help in this co-production (industry-academy) project.

\section{References}

[1] Lacorte, S., Latorre, A., Barceló, D., Rigol, A., Malmqvist, A. and Welander, T. (2003) Organic Compounds in Paper-Mill Process Waters and Effluents. Trends in Analytical Chemistry, 22, 725-737. http://dx.doi.org/10.1016/S0165-9936(03)01009-4

[2] Rintala, J.A. and Puhakka, A. (1994) Anaerobic Treatment in Pulp- and Paper-Mill Waste Management: A Review. Bioresource Technology, 47, 1-18. http://dx.doi.org/10.1016/0960-8524(94)90022-1

[3] Kostamo, A., Holmbom, B. and Kukkonen, J.V.K. (2004) Fate of Wood Extractives in Wastewater Treatment Plants at Kraft Pulp Mills and Mechanical Pulp Mills. Water Research, 38, 972-982. http://dx.doi.org/10.1016/j.watres.2003.10.051

[4] Mobius, C.H. (1999) Wastewater Biofilters Used for Advanced Treatment Of Papermill Effluent. Water Science \& Technology, 40, 101-108. http://dx.doi.org/10.1016/S0273-1223(99)00706-4

[5] Schnell, A., Sabourin, M.J., Skog, S. and Garvie, M. (1997) Chemical Characterization and Biotreatability of Effluents From an Integrated Alkaline-Peroxide Mechanical Pulping/Machine Finish Coated Paper Mill. Water Science and Technology, 235, 7-14. http://dx.doi.org/10.1016/S0273-1223(96)00910-9

[6] Werker A.G. and Hall, E.R. (1999) Limitations for Biological Removal of Resin Acids from Pulp Mill Effluent. Water Science and Technology, 40, 281-288. http://dx.doi.org/10.1016/S0273-1223(99)00729-5

[7] Helble, A., Schlayer, W., Liechti, P-A., Jenny, R. and Mobius, C.H. (1999) Advanced Effluent Treatment in the Pulp and Paper Industry with a Combined Process of Ozonation and Fixed Bed Biofilm Reactors. Water Science \& Technology, 40, 343-350. http://dx.doi.org/10.1016/S0273-1223(99)00737-4

[8] Kaczala, F., Marques, M. and Hogland, W. (2009) Lead and Vanadium Removal from a Real Industrial Wastewater by Gravitation Settling/Sedimentation and Sorption onto Pinus sylvestris Sawdust. Bioresource Technology, 100, $235-243$. http://dx.doi.org/10.1016/j.biortech.2008.05.055

[9] Ayyappan, R., Sophia, A. C., Swaminathan K. and Sandhya, S. (2005) Removal of Pb(II) from Aqueous Solution Using Carbon Derived from Agricultural Wastes. Process Biochemistry, 40, 1293-1299. http://dx.doi.org/10.1016/j.procbio.2004.05.007

[10] Li, Q., Zhai, J., Zhang, W., Wang, M. and Zhou, J. (2007) Kinetics Studies of Sorption of Pb(II), Cr(III) and Cu(II) from Aqueous Solution by Sawdust and Modified Peanut Husk. Journal of Hazardous Materials, 141, 163-167. http://dx.doi.org/10.1016/j.jhazmat.2006.06.109

[11] Shukla, A., Zhang, Y.H., Dubey, P., Margrave, J.L. and Shukla, S.S. (2002) The Role of Sawdust in the Removal of Unwanted Materials from Water. Journal of Hazardous Materials, 95, 137-152. http://dx.doi.org/10.1016/S0304-3894(02)00089-4

[12] Vásquez, G., Antorrena, G., González, J. andDoval, M.D. (1994) Sorption of Heavy Metal Ions by Chemically Modified Pinus pinaster Bark. Bioresource Technology, 48, 251-255. http://dx.doi.org/10.1016/0960-8524(94)90154-6

[13] Al-Qodah, Z. (2006) Biosorption of Heavy Metal Ions from Aqueous Solutions by Activated Sludge. Desalination, 196, 164-176. http://dx.doi.org/10.1016/j.desal.2005.12.012 
[14] Chang, W.C., Hsu, G.S., Chiang, S.M. and Su, M.C. (2006) Heavy Metal Removal from Aqueous Solution by Wasted Biomass from a Combined AS-Biofilm Process. Bioresource Technology, 97, 1503-1508. http://dx.doi.org/10.1016/j.biortech.2005.06.011

[15] Ozsoy, H.D. and Kumbur, H. (2006) Sorption of Cu (II) Ions on Cotton Boll. Journal of Hazardous Materials, 136, 911-916. http://dx.doi.org/10.1016/j.jhazmat.2006.01.035

[16] Ucun, H., Bahyan, Y.K., Kaya, Y., Cakici, A. and Algur, O.F. (2003) Biosorption of Lead(II) from Aqueous Solution by Cone Biomass of Pinus sylvestris. Desalination, 154, 233-238. http://dx.doi.org/10.1016/S0011-9164(03)80038-3

[17] King, P., Srinivas, P., Kumar, Y. P. and Prasad, V.S.R.K. (2006) Sorption of Copper (II) Ions from Aqueous Solution by Tectonagrandis L.F. (Teak Leaves Powder). Journal of Hazardous Materials, 136, 560-566. http://dx.doi.org/10.1016/j.jhazmat.2005.12.032

[18] Saeed, A. and Iqbal, M. (2003) Bioremoval of Cadmium from Aqueous Solution by Black Gram Husk (Cicerarientinum). Water Research, 37, 3472-3480. http://dx.doi.org/10.1016/S0043-1354(03)00175-1

[19] Martínez, M., Miralles, N., Hidalgo, S., Fiol, N., Villaescusa, I. and Poch, J. (2006) Removal of Lead (II) from Aqueous Solutions Using Grape Stalk Waste. Journal of Hazardous Materials, 136, 203-211. http://dx.doi.org/10.1016/j.jhazmat.2005.10.030

[20] Kängsepp, P. (2008) Development and Evaluation of a Filter-Bed-Based System for Full Scale Treatment of Industrial Landfill Leachate. Ph.D. Dissertation, Department of Analytical Chemistry, Lund University, Lund.

[21] Wang, S. and Wu, H. (2006) Environmental-Benign Utilization of Fly Ash as Low-Cost Adsorbents. Journal of Hazardous Materials, 136, 482-501. http://dx.doi.org/10.1016/j.jhazmat.2006.01.067

[22] Genç-Fuhrman, H., Mikkelsen, P.S. and Ledin, A. (2007) Simultaneous Removal of As, Cd, Cr, Cu, Ni and Zn from Stormwater: Experimental Comparison of 11 Different Sorbents. Water Research, 41, 591-602. http://dx.doi.org/10.1016/j.watres.2006.10.024

[23] Shin, E.W., Karthikeyan, K.G. and Tshabalala, M.A. (2007) Adsorption Mechanism of Cadmium on Juniper Bark and Wood. Bioresource Technology, 98, 588-594. http://dx.doi.org/10.1016/j.biortech.2006.02.024

[24] Rivas, F.J., Garcia de laCalle, R., Alvarez, P. and Acedo, B. (2008) Polycyclic Aromatic Hydrocarbons Sorption on Soils: Some Anomalous Isotherms. Journal of Hazardous Materials, 158, 375-383. http://dx.doi.org/10.1016/j.jhazmat.2008.01.083

[25] Lemić, J., Tomasević-Čanović, M., Adamović, M., Kovacević, D. and Miličević, S. (2007) Competitive Adsorption of Polycyclic Aromatic Hydrocarbons on Organo-Zeolites. Microporous and Mesoporous Materials, 105, 317-323. http://dx.doi.org/10.1016/j.micromeso.2007.04.014

[26] Deschamps, G., Caruel, H., Borredon, M.E., Bonnin, C. and Vignoles, C. (2003) Oil Removal from Water by Selective Sorption on Hydrophobic Cotton Fibres. 1. Study of Sorption Properties and Comparison with Other Cotton FibreBased Sorbents. Environmental Science and Technology, 37, 1013-1015. http://dx.doi.org/10.1021/es020061s

[27] Srinivasan, A. and Viraraghavan, T. (2008) Removal of Oil by Walnut Shell Media. Bioresource Technology, 99, 82178220. http://dx.doi.org/10.1016/j.biortech.2008.03.072

[28] Gammoun, A., Tahiri, S., Albizane, A., Azzi, M., Moros, J., Garrigues, S. and de laGuardia, M. (2007) Separation of Motor Oils, Oily Wastes and Hydrocarbons from Contaminated Water by Sorption on Chrome Shavings. Journal of Hazardous Materials, 145, 148-153. http://dx.doi.org/10.1016/j.jhazmat.2006.11.005

[29] Valderrama, C., Gamisans, X., de lasHerras, X., Farran, A. and Cortina, J.L. (2008) Sorption Kinetics of Polycyclic Aromatic Hydrocarbons Removal Using Granular Activated Carbon: Intraparticle Diffusion Coefficients. Journal of Hazardous Materials, 157, 386-396. http://dx.doi.org/10.1016/j.jhazmat.2007.12.119

[30] Memon, S.Q., Memon, N., Shah, S.W., Khuhawar, M.Y. and Bhanger, M.I. (2007) Sawdust-A Green and Economical Sorbent for the Removal of Cadmium (II) Ions. Journal of Hazardous Materials, 139, 116-121. http://dx.doi.org/10.1016/j.jhazmat.2006.06.013

[31] International Organization of Standardization (2004) Water Quality. Application of Inductively Coupled Plasma Mass Spectrometry (ICP-MS)-Part 1: General Guidelines. ISO 17294-1.

[32] Nederlands Normalisatie-Instituut (2008) Soil Quality-Quantitative Determination of the Content of Mineral Oil by Using Gas Chromatography, NEN 6978 (nl), Delft. 